Business and Accounting Education Journal

\title{
PENGARUH ORIENTASI PASAR, ORIENTASI KEWIRAUSAHAAN DAN INOVASI PRODUK TERHADAP KINERJA PEMASARAN UKM
}

\author{
Kiki Zuliasanti, Rusdarti, Wijang Sakitri
}

Jurusan Pendidikan Ekonomi, Fakultas Ekonomi, Universitas Negeri Semarang, Indonesia

\begin{tabular}{l}
\hline Info Artikel \\
\hline Sejarah Artikel: \\
Diterima,27 Januari 2020 \\
Disetujui, 13 Maret 2020 \\
Dipublikasikan,30 Juni \\
2020
\end{tabular}

Keywords:

Entrepreneurship

Orientation; Market

Orientation; Market

Performance; Product

Innovation

\begin{abstract}
Abstrak
Penelitian ini bertujuan untuk menganalisis pengaruh orientasi pasar, orientasi kewirausahaan dan inovasi produk terhadap kinerja pemasaran secara bersama-sama dan parsial. Populasi dalam penelitian ini sebanyak 2.938 UKM Mebel di Kecamatan Tahunan Kabupaten Jepara. Jumlah sampel dalam penelitian ini sebanyak 97 UKM. Teknik pengambilan sampel yang digunakan adalah Proportional Random Sampling. Metode pengumpulan data dengan kuesioner. Teknik analisis data menggunakan statistik deskriptif dan analisis regresi linier berganda.. Hasil penelitian menunjukkan bahwa orientasi pasar, orientasi kewirausahaan dan inovasi produk berpengaruh positif dan signifikan terhadap kinerja pemasaran. Pengaruh simultan sebesar $73 \%$ sedangkan pengaruh secara parsial orientasi pasar sebesar $30,80 \%$, orientasi kewirausahaan sebesar $18,31 \%$, dan inovasi produk sebesar $8,76 \%$. Simpulan penelitian bahwa orientasi pasar, orientasi kewirausahaan dan inovasi produk mempengaruhi kinerja pemasaran.
\end{abstract}

\section{Abstract}

This study aims to analyze the effect of market orientation, entrepreneurial orientation and product innovation on marketing performance together and partially. The population in this study was 2,938 Furniture SMEs in the Annual District of Jepara Regency. The number of samples in this study were $97 \mathrm{SMEs}$. The sampling technique used is Proportional Random Sampling. Data collection method with a questionnaire. Data analysis techniques used descriptive statistics and multiple linear regression analysis. The results showed that market orientation, entrepreneurial orientation and product innovation had a positive and significant effect on marketing performance. The simultaneous effect is $73 \%$ while the partial effect is market orientation by $30.80 \%$, entrepreneurial orientation by $18.31 \%$, and product innovation by $8.76 \%$. Research conclusions that market orientation, entrepreneurial orientation and product innovation affect marketing performance.

Alamat korespondensi:

Gedung L3 Lantai 1 FE Unnes

Kampus Sekaran, Gunungpati, Semarang, 50229

E-mail: kikyzuliamanyun@gmail.com 


\section{PENDAHULUAN}

Dalam menjalankan bisnis, adanya persaingan usaha bukanlah hal yang baru, baik usaha skala besar maupun usaha kecil. Besarnya pertumbuhan usaha saat ini menciptakan persaingan yang sangat ketat. Keadaan ini memaksa para pengusaha untuk menggunakan berbagai cara dalam strategi pemasarannya. Banyak cara yang dilakukan agar usahanya tidak kalah bersaing sehingga masih bisa bertahan bahkan berkembang di tengah persaingan pasar yang semakin ramai.

Begitu pula dengan kegiatan yang dijalankan oleh UKM, sektor usaha berskala kecil ini diarahkan untuk mempertahankan eksistensi bisnisnya dan mengembangkan bisnisnya. UKM di negara berkembang salah satunya di negara Indonesia merupakan sektor usaha yang paling mendominasi. Selain jumlahnya yang jauh lebih banyak dibandingkan usaha berskala besar, UKM disebut sebagai sektor yang mampu menopang perekonomian nasional karena dipercaya mampu bertahan dari tempaan krisis. Lebih dari itu, UKM juga berperan penting dalam penyerapan tenaga kerja di Indonesia. Sektor ini mampu menyediakan lapangan kerja baru bagi masyarakat sehingga membantu mengurangi angka pengangguran.

Keberadaan usaha kecil dan menengah memang memberikan kontribusi yang cukup besar dalam berbagai aspek. Akan tetapi, kegiatan usaha yang dilakukan UKM ini bukan berarti tanpa kendala. Saat ini perkembangan industri kecil dan menengah marak bermunculan namun sulit berkembang. Beberapa industri hampir lenyap dan tidak mampu bersaing dengan usaha besar. Kemampuan daya saing masyarakat dalam tuntutan globalisasi membuka peluang bagi dunia usaha untuk tumbuh menjadi makin berkualitas dengan efisiensi dan kompetitif. Kemampuan pengusaha dalam mengembangkan pilihan strategi di bidang manajemen pemasaran mampu menciptakan produk baru dan persaingan produk dengan produk lainnya dengan mengembangkan produk yang sudah ada menjadi luar biasa. Dalam hal ini meningkatkan kualitasnya, memperbaharui bentuknya, atau mempercantik kemasan produknya.

Kinerja nyata yang dihadapi oleh sebagian besar usaha terutama UKM di Indonesia yang paling menonjol adalah rendahnya tingkat produktivitas, rendahnya nilai tambah, dan rendahnya kualitas produk. Meskipun diakui bahwa UKM menjadi lapangan kerja bagi sebagian pekerja di Indonesia, tetapi kontribusinya dalam output nasional dikategorikan rendah. Persaingan usaha yang begitu ketat mengaharuskan UKM meningkatkan kinerja pemasaran.

Kinerja merupakan gambaran mengenai sejauh mana keberhasilan atau kegagalan organisasi dalam menjalankan tugas dan fungsi pokonya dalam rangka mewujudkan sasaran, tujuan, visi dan misinya (Simamora, 2001:327). Kinerja pemasaran pada umumnya digunakan untuk mengukur dampak dari strategi-strategi perusahaan (Tanoko, 2010:16). Kinerja pemasaran merupakan faktor yang seringkali digunakan untuk mengukur dampak dari strategi yang diterapkan perusahaan (Ferdinand, 2014:190). Kinerja pemasaran sebagai suatu ukuran prestasi dari aktifitas proses pemasaran dapat dipandang sebagai konsep yang digunakan dalam mengukur sampai mana prestasi pasar dapat tercapai oleh perusahaan (Sugiyarti, 2016:645).

Terdapat dua pendekatan untuk mengukur keunggulan kinerja perusahaan. Pendekatan pertama menyatakan bahwa kinerja perusahaan dianggap unggul apabila memiliki kinerja diatas rata-rata (above average perfomance) yang dilihat dari: pangsa pasar, kinerja finansial, dan sebagainya. Pendekatan kedua menilai keunggulan perusahaan yang usianya panjang, yang berarti dapat bertahan dalam waktu yang lama merupakan perusahaan yang kinerjanya unggul (Supratikno, 2006:13). Thor (dalam Wibowo, 2016:157) mengemukakan bahwa pengembangan ukuran kinerja sebagai alat untuk meningkatkan efektivitas organisasi terdapat tiga dasar yaitu, (1) apa yang diukur 
semata-mata ditentukan oleh apa yang dipertimbangkan penting oleh pelanggan. (2) kebutuhan pelanggan diterjemahkan menjadi prioritas strategi dan rencana strategis mengindikasikan apa yang harus diukur. (3) memberikan perbaikan kepada tim dengan mengukur hasil prioritas strategis, memberi kontribusi untuk perbaikan lebih lanjut dengan mengusahakan motivasi tim, dan informasi tentang apa yang berjalan dan tidak berjalan.

Pengukuran kinerja menjadi permasalahan dan perdebatan klasik karena sebagai sebuah konstruk, kinerja pemasaran bersifat multidimensional yang mana di dalamnya termuat beragam tujuan dan tipe organisasi, maka kinerja sebaiknya diukur dengan menggunakan berbagai kriteria pengukuran sekaligus (multiple measurement). Jika menggunakan pengukuran dengan kriteria tunggal (single measurement) maka tidak akan mampu memberikan pemahaman yang komperhensif tentang bagaimana kinerja suatu perusahaan itu sesungguhnya (Prasetya, 2002:227). Kinerja pemasaran merupakan pengukuran prestasi dari seluruh aktivitas proses pemasaran secara menyeluruh sebagai keberhasilan usahanya dalam persaingan bisnisnya serta adanya pertumbuhan yang meningkat dari tahun-tahun sebelumnya. Indikator dari kinerja pemasaran yaitu pertumbuhan penjualan, pertumbuhan pelanggan dan jangkauan wilayah pemasaran.

Agar dapat bersaing dalam persaingan bisnis, maka dalam memasarkan produk tidak hanya berdasarkan pada kualitas produk saja, tetapi juga bergantung pada strategi yang umumnya digunakan oleh perusahaan yaitu orientasi pasar, orientasi kewirausahaan dan inovasi. Menurut Kotler (dalam Sarjita, 2017) pemasaran adalah sebagai suatu proses sosial dan managerial yang membuat individu dan kelompok memperoleh apa yang mereka butuhkan dan inginkan lewat penciptaan dan pertukaran timbal balik produk dan nilai dengan orang lain. Dalam orientasi pasar perlu pengetahuan mengenai jenis pasar yang akan dimasuki, termasuk di dalam karakteristiknya. Dengan demikian dapat diketahui arah yang jelas mengenai orientasi pasar dari produk yang dihasilkan.

Orientasi pasar merupakan perilaku organisasial yang mencakup pengumpulan, penyebaran, dan tanggapan atas intelijen pasar yang tercermin pada orientasi pelanggan, orientasi pesaing dan mekanisme koordinasi dalam menciptakan nilai pelanggan (Sari, 2013:113). Orientasi pasar yang kuat di prusahaan bisa memberikan penawaran dan memberikan kepuasan yang lebih baik kepada pembeli serta perusahaan akan memperoleh hasil yang lebih besar atas penawaran yang diberikan (Prapiani, 2014:16). Orientasi pasar sebagai suatu proses dan aktivitas yang berhubungan dengan penciptaan dan pemuasan pelanggan dengan cara terus menilai kebutuhan dan keinginana pelanggan (Uncles, 2000:1). Orientasi pasar meruapakan budaya perusahaan yang menempatkan pasar sebagai salah satu strategi untuk mempertahankan kelangsungan bisnis suatu perusahaan. Indikator dari orientasi pasar yaitu orientasi pelanggan, orientasi pesaing dan koordinasi antar fungsi.

Kewirausahaan merupakan sikap mental dan sidat jiwa yang selalu aktif dalam berusaha memajukan karya baktinya dalam rangka upaya meningkatkan pendapatan di dalam kegiatan usahanya. Inti dari kewirausahaan adalah kemampuan untuk menciptakan sesuatu yang baru dan berbeda melalui berpikir kreatif dan bertindak inovatif untuk menciptakan peluang dalam menghadapi tantangan hidup (Hadiyati, 2011:10). Penelitian mengenai pengaruh orientasi kewirausahaan terhadap kinerja pemasaran telah banyak dilakukan, namun masih terdapat ketidakkonsistenan. Penelitian yang dilakukan oleh Fatmawati (2015) menyatakan bahwa orientasi kewirausahaan berpengaruh positif dan signifikan terhadap kinerja pemasaran.

Selain itu, penelitian yang dilakukan oleh Aminnudin (2014) menyatakan bahwa orientasi wirausaha UKM akan meningkatkan kinerja pemasaran. Peningkatan kinerja pemasaran dibangun oleh orientasi wirausaha melalui inovasi, berani mengambil risiko dan 
bertindak proaktif. Sedangkan Mulyani dan Mudiantono (2015) dalam penelitiannya menemukan bahwa orientasi kewirausahaan berpengaruh positif dan tetapi tidak signifikan terhadap kinerja pemasaran. Penelitian Djodjobo dan Tawas (2014) juga menyatakan bahwa orientasi kewirausahaan tidak berpengaruh positif dan signifikan terhadap kinerja pemasaran usaha nasi kuning di Kota Manado. Orientasi kewirausahaan merupakan karakteristik dan nilai yang harus dimiliki oleh seorang wirausaha dalam menciptakan produk yang kreatif dan inovatif dengan sikap proaktif dan berani dalam mengambil risiko dalam menentukan pilihan atau tindakan. Indikator dari orientasi kewirausahaan yaitu agresif dalam bersaing, proaktif dan berani mengambil risiko.

Inovasi produk juga dapat dijadikan sebagai salah satu strategi dalam mencapai kinerja pemasaran. Inovasi menjadi semakin penting sebagai sarana bertahan, bukan hanya pertumbuhan menghadapi ketidakpastian lingkungan dan kondisi persaingan bisnis yang semakin meningkat. Inovasi produk akan menciptakan berbagai desain produk, sehingga meningkatkan alternatif pilihan, meningkatkan manfaat atau nilai yang diterima oleh pelanggan, yang pada akhirnya akan meningkatkan kualitas produk sesuai yang diharapkan. Inovasi produk merupakan suatu cara yang penting bagi perusahaan dalam mengembangkan dan pengenalan produk baru atau dikembangkan yang berhasil di pemasaran agar tetap dapat beradaptasi di pasar, teknologi serta pesaing. Indikator dari inovasi produk yaitu kultur inovasi, inovasi teknis dan inovasi administratif.

Kunci keberhasailan UKM untuk dapat menang dalam persaingan yaitu kinerja bisnis terlebih lagi UKM pada saat ini menjadi suatu yang penting dalam menopang petumbuhan Indonesia. Dalam hal ini UKM mebel di Kecamatan Tahunan Kabupaten Jepara merupakan objek penelitian. UKM mebel yang terkenal dengan kualitas ukirnya yang baik adalah mebel Jepara. Mebel Jepara merupakan penghasil utama bagi warga di Kabupaten Jepara. Sebagian penduduk membuka usaha mebel sendiri dan hampir di sepanjang jalan di Jepara berjajar showroom yang memamerkan produk mebel yang berkualitas tinggi. Selain Kabupaten Jepara, terdapat beberapa kabupaten yang merupakan penghasil mebel.

Perkembangan mebel di Kabupaten Jepara dari tahun ke tahun mengalami kenaikan. Hal ini menunjukkan adanya pertambahan industri mebel dari tahun ke tahun dan berdampak pada persaingan yang ketat. Semakin bertambahnya industri mebel maka semakin ketat pula persaingan yang dihadapi. Hal ini disebabkan oleh banyaknya orang yang mulai tertarik dengan dunia bisnis mebel dan keuntungan yang didapatkan tidaklah sedikit.

Tabel 1. Perbandingan Jumlah Unit Usaha

Mebel di Kabupaten Jepara Tahun 2015

\begin{tabular}{lc}
\hline \multicolumn{1}{c}{ Kecamatan } & Jumlah Unit Usaha \\
\hline Kembang & 418 \\
Bangsri & 415 \\
Mlonggo & 540 \\
Pakis Aji & 512 \\
Jepara & 400 \\
Batealit & 437 \\
Tahunan & 2.938 \\
Kedung & 136 \\
Pecangaan & 197 \\
\hline \multicolumn{1}{c}{ Jumlah } & 5.993 \\
\hline
\end{tabular}

Sumber: BPS Kabupaten Jepara, 2018.

Berdasarkan data BPS Kabupaten Jepara tahun 2015, jumlah unit usaha mebel di Kecamatan Tahunan sebanyak 2.938 unit usaha, kemudian disusul Kecamatan Mlonggo dengan jumlah unit usaha sebanyak 540 unit usaha. selanjutnya Kecamatan Batealit sebanyak 437 unit usaha. berdasarkan data di atas dapat diketahui unit usaha mebel yang paling banyak di Kabupaten Jepara adalah Kecamatan Tahunan.

Kecamatan Tahunan yang mempunyai 2.938 unit usaha tersebar di 15 desa di Kecamatan Tahunan Jepara. Diantaranya adalah Kecamatan Tahunan, Senenan, 
Langon, Krapyak, Mangunan, Mantingan, Kecapi, Tegalsambi, Sukodono, Ngabul, Telukawur, Demangan, Petekeyan, Platar, dan Semat. Jenis usaha yang paling paling dominan di Kecamatan Tahunan adalah industri mebel, yaitu sebanyak 2.938 unit usaha. sedangkan desa yang menempati peringkat pertama dengan paling banyak usaha mebel adalah Desa Krapyak sebanyak 418 unit, posisi kedua adalah Desa Tahunan sebanyak 392 unit, selanjutnya Desa Petekeyan sebanyak 336, dan seterusnya. Rata-rata usaha mebel dapat mencapai ratusan unit usaha di setiap desa. Dalam hal ini dapat menimbulkan persaingan yang ketat yang dapat berdampak pada kinerja usaha mebel.

Menurut data yang diperoleh dari Dinas Perindustrian dan Perdagangan Kabupaten Jepara, perkembangan UKM mebel banyak mengalami kenaikan dan penurunan secara signifikan setiap tahunnya. Ada banyak fakor yang mempengaruhi kenaikan dan penurunan UKM mebel. Hal tersebut dapat dilihat pada tabel dibawah ini:

Tabel 2. Penjualan Mebel di Kabupaten Jepara Tahun 2010-2016

\begin{tabular}{|c|c|c|c|c|c|c|}
\hline \multirow[b]{3}{*}{ Tahun } & \multicolumn{3}{|c|}{ Volume Penjualan } & \multicolumn{3}{|c|}{ Nilai Penjualan } \\
\hline & \multirow{2}{*}{$\begin{array}{c}\text { Total } \\
\text { Penjualan } \\
\text { (Unit/Set) }\end{array}$} & \multicolumn{2}{|c|}{ Fluktuasi } & \multirow{2}{*}{$\begin{array}{l}\text { Hasil Penjualan } \\
\text { (Rupiah) }\end{array}$} & \multicolumn{2}{|c|}{ Fluktuasi } \\
\hline & & (Unit/Set) & $\begin{array}{c}\text { Persentase } \\
(\%)\end{array}$ & & (Rupiah) & $\begin{array}{c}\text { Persentase } \\
(\%)\end{array}$ \\
\hline 2010 & 2.11 .460 & - & - & 1.542 .669 .859 & - & - \\
\hline 2011 & 2.308 .404 & 146.944 & $6.8 \%$ & 1.663 .795 .246 & 121.125 .387 & $7.9 \%$ \\
\hline 2012 & 2.648 .824 & 340.420 & $14.7 \%$ & 1.801 .450 .667 & 137.655 .431 & $8.3 \%$ \\
\hline 2013 & 2.416 .601 & -232.223 & $-8.8 \%$ & 1.602 .084 .307 & -19.366 .370 & $-11.1 \%$ \\
\hline 2014 & 2.931 .305 & 514.704 & $21.3 \%$ & 1.987 .046 .836 & 284.962 .529 & $17.8 \%$ \\
\hline 2015 & 2.798 .164 & -133.141 & $-4.5 \%$ & 1.886 .139 .927 & -100.906 .909 & $-5.1 \%$ \\
\hline 2016 & 2.484 .037 & -314.127 & $-11.2 \%$ & 1.691 .359 .384 & -214.780 .543 & $-11.4 \%$ \\
\hline
\end{tabular}

Sumber: Dinas Perindustrian dan Perdagangan Kabupaten Jepara, 2018.

Berdasarkan tabel 2 UKM mebel mengalami kenaikan dan penurunan dari tahun ke tahun. Kenaikan penjualan terjadi pada tahun 2011, 2012, dan 2014, sedangkan penurunan penjualan terjadi pada tahun 2013 , 2015, dan 2016 dengan total penjualan yang terjadi secara fluktuatif. Faktanya, para pelaku usaha UKM mebel sudah berorientasi pasar, berorientasi kewirausahaan serta melakukan inovasi produk sesuai permintaan pasar namun mengalami penurunan penjualan selama dua tahun terakhir yaitu pada tahun 2015 dan 2016.

Orientasi pasar dibutuhkan oleh perusahaan supaya dapat mengetahui kebutuhan produk yang sedang diinginkan oleh konsumen, sehingga perusahaan tersebut dapat menghasilkan produk yang sesuai dengan kebutuhan konsumen. Sedangkan orientasi kewirausahaan, perusahaan harus lebih berani mengeluarkan produk yang lebih berinovatif dan lebih berkembang mengikuti perkembangan zaman.

Seperti yang diketahui dalam usaha mebel, persaingan yang begitu ketat mengakibatkan penurunan omset penjualan, oleh karena itu perlu ditingkatkan lagi kemampuan manajerialnya yaitu pemilik dari usaha mebel harus memiliki jiwa kewirausahaan. Pengusaha mebel harus mampu merencanakan strategi usahanya, merencanakan ide-ide untuk menangkap peluang usaha dalam mencapai kesuksesan. Dalam kenyataanya, para pengusaha masih belum berani mengambil risiko yang mungkin terjadi, rata-rata mereka lebih memilih meniru produk-produk pengusaha yang lebih sukses agar dapat bertahan dalam persaingan. Padahal jika pengusaha mebel lebih 
memprioritaskan orientasi kewirausahaan mereka akan selangkah lebih maju dari pengusaha mebel lainnya.

Selain berorientasi pasar dan kewiruasahaan, para pengusaha mebel Kecamatan Tahunan berinovasi da;am produknya untuk menciptakan produk yang baru di kalangan pasar, akan tetapi masih banyak produk yang tidak laku karena masih banyak produk yang tidak laku yang tidak sesuai selera konsumen, sehingga mereka lebih memilih mengikuti pegusaha yang sudah sukses dulu dalam berinovasi dan meniru produk-produknya untuk meningkatkan omset penjualannya.

Inovasi merupakan cara untuk terus membangun dan mengembangkan organisasi yang dapat dicapai melalui introduksi teknologi baru, aplikasi baru dalam produk dan layanan, pengembangan pasar baru dan memperkenalkan bentuk-bentuk baru organisasi (Widodo, 2013:208). Inovasi adalah sesuatu yang berkenaan dengan barang, jasa atau ide yang dirasakan baru oleh seseorang (Hadiyati, 2011:11).

Inovasi adalah suatu mekanisme perusahaan untuk beradaptasi dengan lingkungan yang dinamis (Prakoso, 2005:189). Inovasi adalah proses pengubahan pengetahuan menjadi nilai melalui penerapan produk, proses dan sistem yang baru atau lebih baik (Ferraresi, 2012:690).

Tujuan penelitian ini adalah untuk menganalisis: (1) pengaruh orientasi pasar terhadap kinerja pemasaran UKM mebel di Kecamatan Tahunan Kabupaten Jepara. (2) Pengaruh orientasi kewirausahaan terhadap kinerja pemasaran UKM mebel di Kecamatan Tahunan Kabupaten Jepara. (3) Pengaruh inovasi produk terhadap kinerja pemasaran UKM mebel di Kecamatan Tahunan Kabupaten Jepara. (4) Pengaruh orientasi pasar, orientasi kewirausahaan dan inovasi produk secara simultan terhadap kinerja pemasaran UKM mebel di Kecamatan Tahunan Kabupaten Jepara.

\section{METODE}

Penelitian ini menggunakan pendekatan deskriptif kuantitatif. Populasi dalam penelitian ini adalah pemilik UKM Mebel di Kecamatan Tahunan Kabupaten Jepara per 2015 yang berjumlah 2.938 unit usaha dan sampelnya sebanyak 97 pemilik UKM. Teknik pengambilan sampel dalam penelitian ini menggunakan teknik Proportional Random Sampling. Teknik pengumpulan data menggunakan kuisioner. Data dianalisis dengan analisis statistik deskriptif, analisis regresi linier berganda dan uji hipotesis.

\section{HASIL DAN PEMBAHASAN}

\section{Deskriptif Variabel Kinerja Pemasaran}

Data mengenai orientasi kewirausahaan UKM mebel di Kecamatan Tahunan diperoleh dari angket dengan jumlah pertanyaan sebanyak 14 butir pertanyaan. Dengan 3 indikator yaitu pertumbuhan penjualan, pertumbuhan pelanggan dan jangkauan wilayah pemasaran. Berdasarkan jawaban dari angket masing-masing pengusaha mebel yang menjadi responden dalam penelitian ini didapatkan gambaran seperti pada tabel sebagai berikut.

Tabel 3. Deskriptif persentase Variabel Kinerja Pemasaran

\begin{tabular}{|c|c|c|c|c|}
\hline No. & $\begin{array}{c}\text { Interval } \\
\text { Skor }\end{array}$ & $\mathbf{F}$ & $\%$ & Kriteria \\
\hline 1 & $60-70$ & 74 & $76,29 \%$ & Sangat Tinggi \\
\hline 2 & $49-59$ & 23 & $23,71 \%$ & Tinggi \\
\hline 3 & $38-48$ & 0 & $0 \%$ & Sedang \\
\hline 4 & $27-37$ & 0 & $0 \%$ & Rendah \\
\hline \multirow[t]{2}{*}{5} & $14-26$ & 0 & $0 \%$ & Sangat Rendah \\
\hline & umlah & 97 & $100 \%$ & \\
\hline \multicolumn{3}{|c|}{ Rata - rata kriteria } & 63,51 & Sangat Tinggi \\
\hline
\end{tabular}

Sumber: Data penelitian diolah, 2018.

Berdasarkan tabel 3 dapat diketahui bahwa pengusaha yang menjadi responden dalam penelitian yaitu jumlah pengusaha yang berada dalam kategori sangat tinggi 74 (76,29\%) dan 23 pengusaha $(23,71 \%)$ dalam kategori tinggi. variabel kinerja pemasaran berada dalam kriteria sangat tinggi dengan rata-rata 63,51. Hal ini menunjukkan bahwa sebagian besar 
pengusaha mebel di Kecamatan Tahunan memiliki kinerja pemasaran yang sangat tinggi. Secara lebih rinci variabel kinerja pemasaran dibagi menjadi tiga indikator.

\section{Deskriptif Variabel Orientasi Pasar}

Data mengenai orientasi pasar di UKM mebel Kecamatan Tahunan Kabupaten Jepara diperoleh dari angket dengan jumlah sebanyak 9 butir pertanyaan dengan 3 indikator yaitu orientasi pelanggan, orientasi pesaing dan koordinasi antar fungsi. Berikut jawaban hasil angket responden dalam penelitian ini yaitu sebagai berikut:

Tabel 4. Deskriptif persentase Variabel Orientasi Pasar

\begin{tabular}{|c|c|c|c|c|}
\hline No. & $\begin{array}{c}\text { Interval } \\
\text { Skor }\end{array}$ & $\mathbf{F}$ & $\%$ & Kriteria \\
\hline 1 & $>39-45$ & 40 & $41,24 \%$ & Sangat Tinggi \\
\hline 2 & $32-38$ & 52 & $53,61 \%$ & Tinggi \\
\hline 3 & $25-31$ & 5 & $5,15 \%$ & Sedang \\
\hline 4 & $18-24$ & 0 & $0 \%$ & Rendah \\
\hline 5 & $9-17$ & 0 & $0 \%$ & Sangat Rendah \\
\hline \multicolumn{2}{|c|}{ Jumlah } & 97 & $100 \%$ & \\
\hline \multicolumn{4}{|c|}{ Rata - rata kriteria 38,76} & Tinggi \\
\hline
\end{tabular}

Berdasarkan tabel 4 dapat diketahui pengusaha yang menjadi responden dalam penelitian yaitu jumlah pengusaha yang berada dalam kategori sangat tinggi $40(41,24 \%), 52$ pengusaha $(53,61 \%)$ dalam kategori tinggi dan 5 pengusaha $(5,15 \%)$ dalam kategori sedang. variabel orientasi pasar berada dalam kriteria tinggi dengan rata-rata 38,76 . Hal ini menunjukkan bahwa sebagian besar UKM mebel di Kecamatan Tahunan Kabupaten Jepara memiliki orientasi pasar tinggi. Secara lebih rinci variabel orientasi pasar dibagi menjadi tiga indikator.

\section{Deskriptif Variabel Orientasi Kewirasahaan}

Data mengenai orientasi kewirausahaan UKM mebel di Kecamatan Tahunan diperoleh dari angket dengan jumlah pertanyaan sebanyak 9 butir pertanyaan dengan 3 indikator yaitu agresif dalam bersaing, proaktif, dan berani mengambil risiko. Berdasarkan jawaban dari angket masing-masing pengusaha mebel yang menjadi responden dalam penelitian ini didapatkan gambaran seperti pada tabel 5 sebagai berikut:

Tabel 5. Deskriptif persentase Variabel Orientasi Kewirausahaan

\begin{tabular}{|c|c|c|c|c|}
\hline No & $\begin{array}{c}\text { Interval } \\
\text { Skor }\end{array}$ & $\mathbf{F}$ & $\%$ & Kriteria \\
\hline 1 & $39-45$ & 58 & $59,79 \%$ & Sangat Tinggi \\
\hline 2 & $32-38$ & 36 & $37,11 \%$ & Tinggi \\
\hline 3 & $25-31$ & 3 & $3,09 \%$ & Sedang \\
\hline 4 & $18-24$ & 0 & $0 \%$ & Rendah \\
\hline 5 & $9-17$ & 0 & $0 \%$ & Sangat Rendah \\
\hline & Jumlah & 97 & $100 \%$ & \\
\hline \multicolumn{3}{|c|}{ Rata - rata kriteria } & 39,12 & Sangat Tinggi \\
\hline
\end{tabular}

Berdasarkan tabel 5 dapat diketahui bahwa pengusaha yang menjadi responden dalam penelitian yaitu jumlah pengusaha yang berada dalam kategori sangat tinggi 58 $(59,79 \%), \quad 36$ pengusaha $(37,11 \%)$ dalam kategori tinggi dan 3 pengusaha $(3,09 \%)$ dalam kategori sedang. variabel orientasi kewirausahaan berada dalam kriteria tinggi dengan rata-rata sebasar 39,12. Hal ini menunjukkan bahwa sebagian besar UKM mebel di Kecamatan Tahunan Kabupaten Jepara memiliki orientasi kewirausahaan tinggi. Secara lebih rinci variabel orientasi kewirausahaan dibagi menjadi tiga indikator.

\section{Deskriptif Variabel Inovasi Produk}

Data mengenai orientasi kewirausahaan UKM mebel di Kecamatan Tahunan diperoleh dari angket dengan jumlah pertanyaan sebanyak 9 butir pertanyaan dengan 3 indikator yaitu kultur inovasi, inovasi teknis, dan inovasi administratif. Berdasarkan jawaban dari angket masing-masing pengusaha mebel yang menjadi responden dalam penelitian ini didapatkan gambaran seperti pada tabel 6 sebagai berikut: 
Tabel 6. Deskriptif persentase Variabel Inovasi Produk

\begin{tabular}{|c|c|c|c|c|}
\hline No & $\begin{array}{c}\text { Interval } \\
\text { Skor }\end{array}$ & $\mathbf{F}$ & $\%$ & Kriteria \\
\hline 1 & $39-45$ & 25 & $25,77 \%$ & Sangat Tinggi \\
\hline 2 & $32-38$ & 69 & $71,13 \%$ & Tinggi \\
\hline 3 & $25-31$ & 3 & $3,09 \%$ & Sedang \\
\hline 4 & $18-24$ & 0 & $0 \%$ & Rendah \\
\hline 5 & $9-17$ & 0 & $0 \%$ & Sangat Rendah \\
\hline & umlah & 97 & $100 \%$ & \\
\hline \multicolumn{3}{|c|}{ Rata - rata kriteria } & 36,38 & Tinggi \\
\hline
\end{tabular}

Sumber: Data primer yang diolah, 2018.

Berdasarkan tabel 6 dapat diketahui bahwa pengusaha yang menjadi responden dalam penelitian yaitu jumlah pengusaha yang berada dalam kategori sangat tinggi 25 $(25,77 \%), 69$ pengusaha $(71,13 \%)$ dalam kategori tinggi dan 3 pengusaha $(3,09 \%)$ dalam kategoori sedang. variabel inovasi produk berada dalam kriteria tinggi dengan rata-rata sebasar 36,38. Hal ini menunjukkan bahwa sebagian besar UKM mebel di Kecamatan Tahunan Kabupaten Jepara memiliki inovasi produk tinggi. Secara lebih rinci variabel inovasi produk dibagi menjadi tiga indikator.

Untuk mengetahui bagaimana hubungan linier yang terjadi antara variabel orientasi pasar, orientasi kewirausahaan, dan inovasi produk terhadap kinerja pemasaran UKM mebel di Kecamatan Tahunan Kabupaten Jepara maka perlu mengetahui persamaan garis regresinya. Hasil analisis regresi linier berganda diperoleh hasil yang terangkum pada tabel 7 .
Tabel 7. Hasil Analisis Regresi Linier Berganda

\begin{tabular}{|c|c|c|c|c|c|}
\hline \multicolumn{6}{|c|}{ Coefficients $^{\mathrm{a}}$} \\
\hline \multirow[t]{2}{*}{ Model } & $\begin{array}{r}\text { Unstan } \\
\text { Coef }\end{array}$ & $\begin{array}{l}\text { lardized } \\
\text { cients }\end{array}$ & $\begin{array}{c}\text { Standa } \\
\text { rdized }\end{array}$ & $\mathrm{t}$ & Sig. \\
\hline & B & $\begin{array}{l}\text { Std. } \\
\text { Error }\end{array}$ & Beta & & \\
\hline $\begin{array}{c}\text { (Cons } \\
\operatorname{tant})\end{array}$ & 5,755 & 3,780 & & 1,522 & ,131 \\
\hline OP & 621 & 097, & 454 & 6,433 & ,000 \\
\hline $\begin{array}{c}\text { OKW } \\
\text { U }\end{array}$ & 508, & 111, & 332, & 4,568 & ,000 \\
\hline IP & ,351 & ,117 & ,210 & 2,993 & ,004 \\
\hline
\end{tabular}

a. Dependent Variable: Kinerja Pemasaran

Sumber: Data penelitian diolah, 2018

Berdasarkaan tabel 7 diperoleh persamaan regresi sebagai berikut:

$\mathrm{Y}=5,755+0,621 \mathrm{X}_{1}+0,508 \mathrm{X}_{2}+0,351 \mathrm{X}_{3}$

Persamaan regresi tersebut dapat diartikan sebagai berikut: (1) Konstanta = 5,755. Hasil analisis regresi berganda menunjukkan konstanta sebear 5,755. Hal ini menunjukkan bahwa jika nilai semua variabel bebas $=0$ maka kinerja pemasaran akan mengalami kenaikan sebesar 5,755 dengan asumsi variabel dianggap tetap. (2) Koefisien $\mathrm{X}_{1}=0,621$. Jika variabel orientasi pasar mengalami peningkatan sebesar satu point, maka akan menyebabkan kinerja pemasaran naik sebesar 0,621 point dengan asumsi orientasi kewirausahaan dan inovasi produk dianggap tetap. (3) Koefisien $X_{2}=0,508$. Jika variabel orientasi kewirausahaan mengalami peningkatan sebesar satu point, maka akan menyebabkan kinerja pemasaran naik sebesar 0,508 point, dengan asumsi orientasi pasar dan inovasi produk dianggap tetap. (4) Koefisien $\mathrm{X}_{2}=0,351$. Jika variabel inovasi produk mengalami peningkatan sebesar satu point, maka akan menyebabkan kinerja pemasaran naik sebesar 0,351 point, dengan asumsi orientasi pasar dan orientasi kewirausahan dianggap tetap.

Hasil penelitian yang telah dianalisis menunjukkan bahwa besarnya Adjusted $R$ Square sebear 0,730 yang artinya bahwa sebesar $73 \%$ variabel kinerja pemasaran dapat 
dijelaskan oleh variasi tiga variabel bebas yaitu orientasi pasar, orientasi kewirausahaan, dan inovasi produk atau dengan kata lain variabel kinerja pemasaran dapat dipengaruhi oleh variabel orientasi pasar, orientasi kewirausahaan, dan inovasi produk sebesar $73 \%$ sedangkan sisanya $27 \%$ dipengaruhi oleh variabel lain diluar penelitian.

Hasil nilai koefisien determinasi parsial untuk variabel orientasi pasar adalah sebesar 0,555 dengan demikian maka besarnya $\mathrm{r}^{2}$ variabel orientasi pasar sebesar $(0,555)^{2}$ atau 0,308 . Hal ini menunjukkan bahwa besarnya pengaruh variabel orientasi pasar terhadap kinerja pemasaran sebesar 30,80\%. Koefisien parsial untuk variabel orientasi kewriausahaan sebesar $(0,428)^{2}$ atau 0,183. Hal ini menunjukkan bahwa besarnya pengaruh variabel orientasi kewirausahaan terhadap kinerja pemasaran sebesar $18,31 \%$. Koefisien parsial untuk inovasi produk sebesar $(0,296)^{2}$ atau 0,087. Hal ini menunjukkan bahwa besarnya pengaruh variabel inovasi produk terhadap kinerja pemasaran sebesar $8,76 \%$.

\section{Pengaruh Orientasi Pasar terhadap Kinerja Pemasaran UKM Mebel di Kecamatan Tahunan Kabupaten Jepara}

Hasil penelitian menunjukkan bahwa orientasi pasar berpenagruh secara signifikan terhadap kinerja pemasaran UKM mebel di Kecamatan Tahunan Kabupaten Jepara, yang ditunjukkan dari hasil pengujian secara parsial sebesar $30,80 \%$ dapat diartikan bahwa raatrata responden dalam penelitian ini memberikan tanggapan sangat setuju dalam penentuan dan mempertimbangkan faktor orientasi pasar yaitu orientasi pelanggan, orientasi pesaing dan koordinasi antar fungsi. Besarnya kontribusi variabel orientasi pasar tersebut dikarenakan pengusaha cenderung menilai orientasi pasar termasuk dalam kategori sangat baik, karena pengusaha mampu memahami dan mengerti benar keinginan konsumen. Dengan demikian orientasi pasar pada UKM mebel di Kecamatan Tahunan Kabupaten Jepara memegang peran penting dalam meningkatkan kinerja pemasaran. Karena dengan berorientasi pasar dapat meningkatkan kinerja pemasaran yang baik.

Hasil penelitian tersebut sejalan dengan penelitian terdahulu yang dilakukan oleh Pertiwi dan Siswoyo (2016) menyatakan bahwa variabel orientasi pasar berpengaruh positif dan signifikan terhadap kinerja pemasaran dan besar pengaruhnya sebesar $86,7 \%$. Pengaruh antara orientasi pasar terhadap kinerja pemasaran adalah positif, sehingga dapat dikatakan bahwa perusahaan yang melakukan orientasi pasar dengan baik akan meningkatkan kinerja pemasaran perusahaan. Hasil penelitian juga sejalan dengan penelitian Fatmawati (2015) yang menemukan bahwa terdapat pengaruh positif dan signifikan orientasi pasar terhadap kinerja pemasaran.

\section{Pengaruh Orientasi Kewirausahaan Terhadap Kinerja Pemasaran UKM Mebel di Kecamatan Tahunan Kabupaten Jepara}

Hasil uji hipotesis secara parsial (uji t) menunjukkan bahwa variabel orientasi kewirausahaan memiliki nilai signifikansi sebesar 0,000 dan lebih kecil 0,05. Hasil tersebut menyatakan bahwa terdapat pengaruh positif orientasi kewirausahaan terhadap kinerja pemasaran. Dalam koefisien determinasi parsial $\left(\mathrm{r}^{2}\right)$ menunjukkan bahwa besarnya pengaruh orientasi kewirausahaan terhadap kinerja pemasaran sebesar 18,31\%. Orientasi kewirausahaan memberikan kontribusi untuk meningkatkan kinerja pemasaran UKM mebel di Kecamatan Tahunan Kabupaten Jepara. Pengusaha sudah memiliki keagresifan untuk berwirausaha, keaktifan bersaing, dan keberanian mengambil risiko seperti membuka usaha baru, memperkenalkan produk melalui pameran dan tanggap terhadap peluang pasar untuk meningkatkan kinerja usaha.

Hasil penelitian ini sejalan dengan penelitian Fatmawati (2015) yang menemukan adanya pengaruh positif dan signifikan orientasi kewirausahaan terhadap kinerja pemasaran. Hasil penelitian juga sejalan dengan penelitian Mulyani dan Mudiantono 
(2015) yang menemukan bahwa orientasi kewirausahaan berpengaruh signifikan terhadap kinerja perusahaan.

\section{Pengaruh Inovasi Produk Terhadap Kinerja Pemasaran UKM Mebel di Kecamatan Tahunan Kabupaten Jepara}

Berdasarkan hasil penelitian, dapat diketahui nilai signifikansinya kurang dari 0,05 yaitu sebesar 0,04 , nilai $t$ hitung lebih besar dari 1,980 yaitu sebesar 2,993 dan besar pengaruhnya sebesar 0,296 . Hasil tersebut membuktikan bahwa inovasi produk berpengaruh signifikan terhadap kinerja pemasaran. Inovasi memberikan kontribusi untuk meningkatkan kinerja pemasaran bagi pengusaha UKM mebel di Kecamatan Tahunan Kabupaten Jepara. Dengan melakukan inovasi produk maka dapat mempertahankan pelanggan. Pelanggan akan tertarik untuk membeli produk yang lebih unik dengan kualitas yang baik, sehingga inovasi mampu meningkatkan kinerja pemasaran perusahaan.

Inovasi merupakan cara untuk terus membangun dan mengmbangkan organisasi yang dapat dicapai melalui introduksi teknologi baru, aplikasi baru dalam produk dan pelayanan, pengembangan pasar baru dan memperkenalkan bentuk-bentuk baru organisasi (Widodo, 2013:208). Hasil penelitian ini sesuai dengan penelitian Mulyani (2015) bahwa inovasi mempengaruhi kinerja pemasaran. Penelitian Hult, dkk. (2004) juga menemukan bahwa inovasi mampu meningkatkan kinerja pemasaran. Perusahaan yang melakukan inovasi terus-menerus akan meningkatkan kinerja pemasaran. Inovasi kultur, teknis maupun administrasi yang dilakukan perusahaan akan mampu menarik perhatian pelanggan.

\section{SIMPULAN}

Simpulan penelitian ini yaitu: (1) terdapat pengaruh positif dan signifikan orientasi pasar terhadap kinerja pemasaran sebesar $30,80 \%$. (2) Terdapat pengaruh positif dan signifikan orientasi kewirausahaan terhadap kinerja pemasaran sebesar 18,31\%. (3) Terdapat pengaruh positif dan signifikan inovasi produk terhadap kinerja pemasaran sebesar $8,76 \%$. (4) Terdapat pengaruh positif dan signifikan orientasi pasar, orientasi kewirausahaan dan inovasi produk terhadap kinerja pemasaran sebesar $73 \%$ sedangkan sisanya $27 \%$ dipengaruhi oleh variabel lain diluar penelitian.

\section{DAFTAR PUSTAKA}

Aminnudin, Moch. (2014). Upaya Peningkatan Kinerja Pemasaran dengan Faktor Lingkungan Sebagai Variabel Moderat. $J D E B$, Vol. 11 No 2 Oktober.

Djodjobo, Chyntia V, dan H.N. Tawas. (2014). Pengaruh Orientasi Kewirausahaan, Inovasi Produk, dan Keunggulan Bersaing Terhadap Kinerja Pemasaran Usaha Nasi Kuning di Kota Manado. Jurnal EMBA, Vol. 2 No 3, September.

Fatmawati, Rossa Amalia. (2015). Pengaruh Orientasi Pasar, Orientasi Kewirausahaan Terhadap keunggulan Bersaing dan Kinerja Pemasaran (Pada Warung Kucingan/Angkringan di Kota Semarang). Jurnal UNDIP.

Ferraresi, Alex A. (2012). Knowledge Management and Strategic Orientation: Leveraging .innovattiveness and Perfomence. Journal of Knowledge Management, Vol. 16, No. 5, hal. 688701.

Ferdinand, Augusty. (2014). Structural Equation Modeling : Dalam Penelitian Manajemen 5th ed. Semarang: Badan Penerbit Universitas Diponegoro.

Hadiyati, E. (2011). Kajian Pendekatan Pemasaran Kewirausahaan dan Kinerja Penjualan Usaha Kecil. Jurnal Manajemen dan Kewirausahaan. 
Hult, G.T.M., Hurley, R.F. \& Knightc, G.A. (2004). Exploring the relationship between organisation structure and perceived innovation in the manufacturing sector of India. Industrial Marketing Management, 33, pp. 429-438.

Mulyani, Ida T., dan Mudiantono. (2015). Upaya Menigkatkan Kinerja Pemasaran Melalui Orientasi Pasar dan Orientasi Kewirausahaan Dengan Inovasi Produk Sebagai variabel Intervening. Diponegoro Journal of manaagement, Vol. 4, No 3.

Pertiwi, Yunita Dwi. Dan Bambang Banu Siswoyo. (2016). Pengaruh Orientasi Pasar Terhadap Kinerja Pemasaran UMKM Kripik Buah di Kota Batu. Syariah Paper Accounting FEB UMS, hal: 231-238.

Prakoso, Bagas. (2005). Pengaruh Orientasi Pasar, Inovasi an Orientasi pembelajaran Terhadap Kinerja Perusahaan Untuk Mencapai Keunggulan Bersaing (Studi Empiris Pada Industri manufaktur Di Semarang). Jurnal Studi Manajemen dan Organisasi. Vol. 2 No. 1.

Prapiani, Yanu Arika. (2014). Membangun Kinerja Pemasaran Usaha Mikro Kecil dan Menengah Mebel di Kabupaten Jepara (Studi Kasus pada UMKM Mebel di Jepara). Semarang: Skripsi. UNDIP.

Prasetya, Dicky Imam. (2002). Lingkungan Eksternal, Faktor Internal, dan Orientasi Pasar, Pengaruhnya terhadap Kinerja Pemasaran. Jurnal Sains Pemasaran Indonesia, Vol. 1 No. 3, Desember.

Sari, L. F. (2013). Pengaruh Orientasi Pasar dan Kreativitas tergadap Kinerja Pemasaran Pedagang Pakaian jadi di Pasar Kliwon Kabupaten Kudus. Jurnal Analisis Manaemen. 2(1), hal. 110-116.
Simamora, Bilson. (2001). Memenangkan Pasar dengan Pemasaran Efektif dan Profitabel. Edisi Pertama. Jakarta: PT. Gramedia Pustaka Utama.

Sugiyarti, Gita .(2016). Analisis Kinerja Pemasaran Usaha Kecil Menengah Batik Di Provinsi Jawa Tengah. Jurnal Unisbank Semarang, Hal. 645.

Supratikno, Hendrawan, dkk. (2006). Manajemen Kinerja untuk Menciptakan Keunggulan Bersaing. Yogyakarta: Graha Ilmu.

Tanoko, Hendro. (2010). Kontributor Kinerja Pemasaran Dari Aspek Reward, Individu dan Kreatifitas Strategi Pemasaran. Jurnal Dinamika Manajemen. Vol. 1, No. 2, hal: 115-124.

Uncles, M. (2000). Marketing Orientation. Australian Journal of Management. Vol. 25, No. 2.

Wibowo. (2016). Manajemen Kinerja - Edisi Kelima. Jakarta: PT RajaGrafindo.

Widodo. (2013). Model Peningkatan Kinerja UKM berbasis Orientasi Entrepreneur. Jurnal Dinamika Manajemen, 4(2), Hal. 204-219. 